\title{
Cooperative Housing and Cohousing in Canada: The Pursuit of Happiness in the Common Courtyards
}

\section{The Pursuit of Happiness}

Happiness is fundamental to people's livelihoods and the continuity of humankind; it is one of humanity's perpetual pursuits. The United Nations' World Happiness Report $2012^{[1]}$ reflects a new worldwide call for more attention to happiness as a criterion for government policies.

Happiness as important to society is not new. To enlightenment thinkers, the fundamental driving force for humanity is the quest for happiness. Many biological, psychological, philosophical, and religious approaches have striven to define happiness and identify its sources. Ancient Greek philosophers such as Plato (424348 BCE) in Protagoras [2] argued that happiness is the harmony of the soul, whereas Aristotle (384322 BCE) in 'Art' of Rhetoric [3] and Nicomachean Ethics ${ }^{[4]}$ maintained that happiness consists of lifetime activity in the pursuit of highest virtue. Likewise, Roman philosopher Seneca (ca. 4 BCE-65 $\mathrm{CE}$ ) in a dialogue On Happy Life ${ }^{[5]}$ advocated virtue against pleasure. A contemporary definition of happiness is the "subjective enjoyment of one's life as-a-whole" [6].

In his Declaration of Independence, Thomas Jefferson (1743-1826) regarded "the pursuit of happiness" as important as life and liberty in the United States. Utilitarian thinkers, notably English philosopher Jeremy Bentham (1748-1832), demanded public policy to promote "the greatest happiness of the greatest number" [7].

Since the 20th century, various research groups have endeavored to apply scientific methods to discover what 'happiness' is, and how people might attain it.
Happiness economics is a quantitative inquiry, typically combining with other fields such as psychology, sociology, or its related subjects, for instance, quality of life, life satisfaction, positive and negative effects, wellbeing, and so on, to study happiness.

Although most happiness economics research findings show that on average, wealthier countries are happier than poor ones, and that within countries wealthier people are happier than poor ones [8-10], the studies conducted by Richard Easterlin in 1974 and Charles Kenny in 1999 indicate that once a certain standard of living is achieved, there is no clear link between increased wealth and happiness [11-14]. Yet even among the poorer countries, there is no obvious relationship between average income and happiness, suggesting many other factors, including cultural traits, is at work ${ }^{[11]}$. This result indicates that constant craving for more economic gains at the expense of environmental poverty will not lead humanity to greater happiness.

Happiness is therefore a holistic state that needs to be assessed using more than economic measures. Bhutan's Gross National Happiness (GNH) Index established in 1972 is the first of its kind not relying on the Gross National Product (GNP) Index to evaluate happiness, and China's Happiness Index enacted at the end of 2007 is part of its campaign to create a harmonious society.

Studies have shown that sunny weather makes people happier than gloomy days, ${ }^{[13,14]}$ so do genes and personality ${ }^{[1,13,15-16]}$. There is a variation of happiness: having a sense of goal or purpose in life (in Greek terms, 'eudaimonia' or 'eudaimonism' ${ }^{[17]}$ ), enjoying shortterm pleasure (in Greek words, 'hedonia' or 'hedonism' ${ }^{[18]}$ ), having

\begin{abstract}
This paper investigates residents living experience in the common courtyards of cooperative housing and cohousing in Canada, and their sense of happiness associated with it. Cooperative housing as a form of social housing established in Toronto, Ontario, Canada as early as the 1910s. Cohousing as its subsequent name has evolved into a global movement since the 1960s, to promote residents sharing and caring for one another through active participation in community lives and cooperative management. A key feature of this housing is the inclusion of shared spaces, such as common courtyards. This research explored what make residents happy and/or unhappy in the common courtyards, and how to improve their living experience in the common courtyards. Semistructured interviews were conducted with 20 residents in three cooperative housing in Toronto and three cohousing across Canada. The findings suggest that the Courtyard is a central component to promote social happiness of residents. The paper contributes to the topic of Housing and Happiness that is rarely studied. It finally proposes a courtyard garden housing system that can be a template for universal application. The main conclusion is that there is a need for more courtyard configuration in contemporary Canadian urban planning and architectural design to promote community development.
\end{abstract}

Key words: Housing;happiness; courtyard garden; common ground; shared living

Published online: 31st January, 2018

a religion or spirituality, gaining wisdom, or having companions $[13,15$, $16,19-27]$ 


\section{The happy city movement}

The Happy City movement that is changing the structure and soul of cities around the world is documented by Charles Montgomery ${ }^{[17]}$ in his book Happy City, where he states that "The City Has Always Been a Happiness Project" since ancient Greek and Roman times. Drawn from the insights of philosophers, psychologists, neuroscientists, and happiness economists, Montgomery summarized a set of happy city principles as follows:

1. The city should strive to maximize joy and minimize hardship.

2. The city should lead people towards health rather than sickness.

3. The city should offer people real freedom to live, move, and build our lives as we wish.

4. The city should build resilience against economic and environmental shocks.

5. The city should be fair in the way it allocates space, services, mobility, joys, hardships, and costs.

6. The city should, most of all, enable people to build and strengthen the bonds between friends, families, and strangers that give life meaning, bonds that represent the city's greatest achievement and opportunity.

7. The city that acknowledges and celebrates humanity's common fate, that opens doors to empathy and cooperation, will help people tackle the great challenges of the 21st century ${ }^{[17]}$.

His outline demands that a society should have democracy, human rights, environmental health, economic stability, and strong social ties as the basis for building a happy city. Well-designed cities are just one of the elements that contribute to happiness, though design may have big impacts on the above aspects, as Winston Churchill's famous quote says: "We shape our buildings; thereafter they shape us."

\section{The happy home concept}

A happy home is a vital component of a happy city, and the concept has revived internationally. Countries such as Canada, the USA, the UK, Australia, China, among others, have all incorporated happiness criteria into their new housing designs or old housing renovations ${ }^{[28]}$.

James Hamilton's ${ }^{[29]}$ Happy Home: Affectionately Inscribed to the Working People is a historic account on how to live a happy life by following God's Way according to the Christian Bible. Marion Harland's [30] Secret of a Happy Home is another classic on how to maintain harmonious family relations. And D. James Kennedy's [31] Secret to a Happy Home sets the principles for a successful marriage and educating children. Other volumes on the topic offer practical guidance on designing architectural exteriors and interiors to make homes visual delights $^{[32-35]}$.

Seattle-based American architect, Ross Chapin ${ }^{[36]}$, in his book Pocket Neighborhoods, explored design solutions for buildings and outdoor spaces to support personal and family life and foster a sense of community through informal arrangements with neighbors. Chapin believes that groupings of 4-12 households will make walkable, human-scale communities where important neighborly relationships are formed and cultivated, since strong connections between neighbors develop most naturally and fully when everyone shares a common space, such as a garden courtyard or a series of joined backyards.

In his article "How to Design Our Neighborhoods for Happiness," Jay Walljasper [37] noted that when people share their yards and common spaces, they find a greater sense of connection to those around them. Walljasper mentioned his experience living in a row house with a common courtyard near the campus of the University of Minnesota, and recalled it being the only time in his life that he became close friends with his neighbors who shared spontaneous afternoon conversations at the picnic table, and parties that went into the early mornings. When the property was sold to a speculator who raised the rents to accumulate capital for demolishing the building, the tenants organized and won a strike. The house still stands today, and he remains in contact with some of the old friends that partied in the courtyard.

The above story resonates Harvard University Professor Robert Putnam's contention that "the single most common finding from a half century's research on the correlates of life satisfaction...is that happiness is best predicted by the breadth and depth of one's social connections" [38].

Influenced by the "Garden City" movement ${ }^{[1]}$ in 1898 in the UK, cooperative housing with common courtyards started in Toronto, Canada as early as 1910. The examples are the Three Streets Housing Cooperative (b. 1910), Bain Apartments Cooperative (former "Riverdale Courts," b. 1913-1920s, figure 1), and Spruce Court Housing Cooperative (b. 1913-1926). The latter two projects were designed in English Tudor style by Toronto architect Eden Smith (1858-1949). This unique set of buildings was the first social housing in Canada constructed by the Toronto Housing Authority. The Bain Apartments Cooperative was incorporated in 1977 as one of the first housing cooperatives in

[1] The Garden City movement was initiated by Sir Ebenezer Howard as a response to the congested and unhealthy conditions of working-class housing constructed during the industrial revolution. A key concept of the movement was the inclusion of green space into urban districts through appropriate site planning. 
Ontario ${ }^{[39]}$.

Since the 1980s, cooperative housing revived and was built by the Cooperative Housing Federation of Canada. In 2013 at the time of the survey, 16 of 53 (30 percent) cooperative housing in Toronto have identified with one or more courtyards. The Toronto cooperative housing with common courtyards include Arcadia Housing Cooperative, Church-Isabella Residence Cooperative (b. 1917), Courtyard Housing Cooperative (b. 1993), Hugh Garner Housing Cooperative (b. 1982), Jenny Green Cooperative Homes, New Hibret Cooperative Homes (b. 1996), Oak Street Housing Cooperative (b. 1987), Peggy and Andrew Brewin Housing Cooperative (b. 1995),
Windward Cooperative Homes (b. 1986), among others.

Inspired by Danish models in the 1960s, the Canadian Cohousing Network (CCN, formed in 1992) is part of a global cohousing initiative ${ }^{[40]}$. The design of these communities promotes social interactions through common courtyards and community gardens, as well as a common house with shared facilities. These self-managed communities create social ties that help achieve a high quality of life, and cars are generally kept at the perimeter of the community properties ${ }^{[38,41-45]}$.

Cohousing is gaining popularity in North America. In 2013-2017, CCN endorsed 27 cohousing projects across Canada ${ }^{[40]}$, although some are still in the planning and development stages. For example, Cranberry Commons Cohousing in Vancouver suburb Burnaby, WindSong Cohousing Community in Langley (British Columbia), and Wolf Willow Cohousing in downtown Saskatoon, all incorporated common courtyards. In 2013, the Cohousing Association of the United States listed 213 cohousing communities on their website; and by the end of 2017, it increased to 330, with another 140 being formed ${ }^{[46]}$.

The siheyuan, or courtyard houses of Beijing ${ }^{[47-52]}$, in recent decades have the courtyards often shared by 10 different families, and are thus similar in some respects to cohousing.

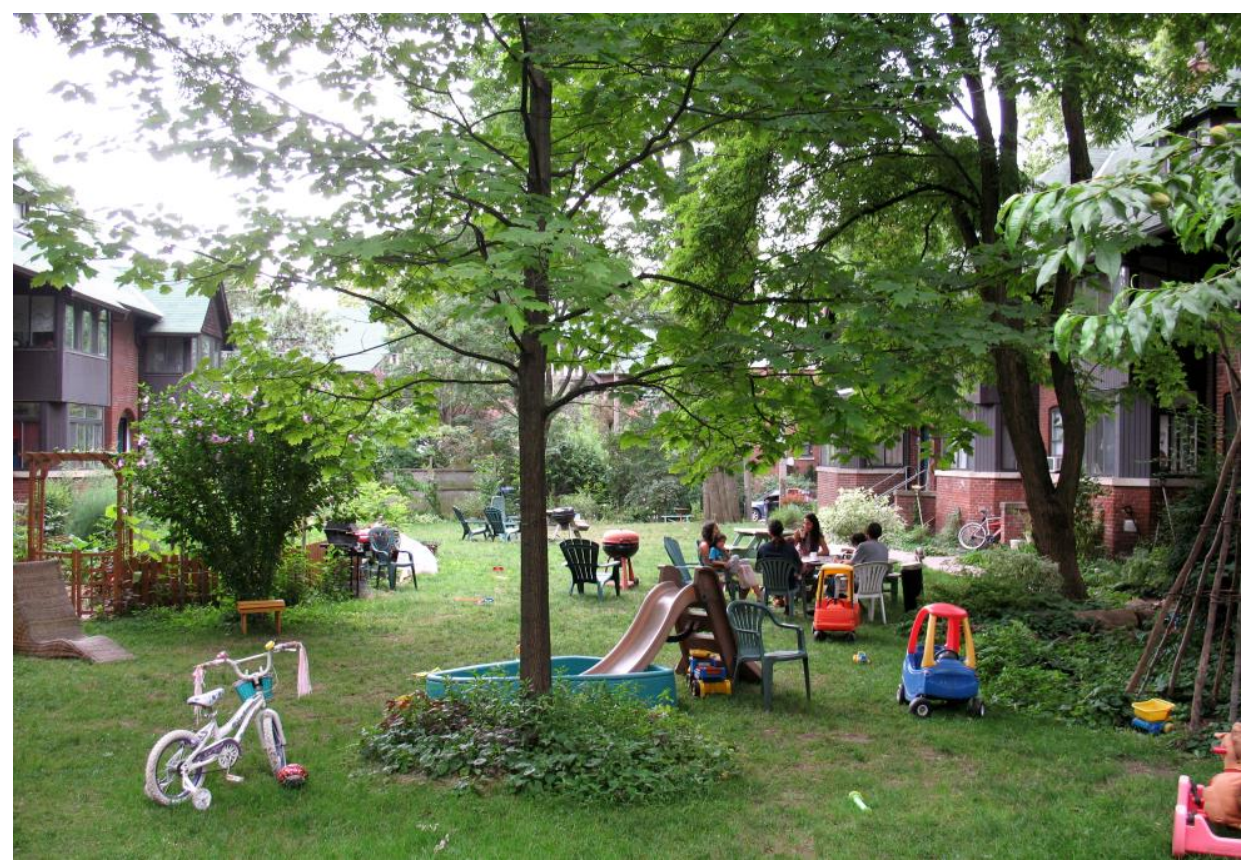

Figure 1. Bain apartments cooperative, north maples courtyard, Toronto, Ontario, Canada. Source: Photo by the author 2013

\section{Research methods}

This empirical qualitative research examined residents' social and behavioral aspects in six cooperative housing and cohousing communities in Canada. The study was ethically endorsed by the City Institute at York University, and honorably advised by the SUNY Distinguished Professor Emeritus, Dr Ronald G. Knapp, and Professor/Dr Richard
Harris at McMaster University. Data included interviews, photos, drawings, flyers, and brochures. After each Community's Board of Directors agreed on the research, the researcher conducted the interviews in October and November 2013. Generally, a chief person in each community distributed the questionnaire to their residents. Some respondents emailed the researcher back their completed questionnaires, while others mailed back their completed questionnaires in sealed envelopes within two weeks. There were 20 respondents from three cooperative housing in Toronto and three cohousing across Canada (two in British Columbia and one in Saskatchewan). They answered three semi-structured interview questions: (1) What are the things that make you happy in the common courtyard (2) What are 
the things that make you unhappy in the common courtyard? (3) What can be done to improve your living experience in the common courtyard?

These three questions were presented on an A4 sheet of a MSWord document, with equal spacing underneath each question for the respondent to fill in. Each interviewee was later given a unique ID for his/her interview data. The researcher then put together all the answers from all the respondents on a separate file for content analysis using MS Word. No other data analysis software (e.g., NVivo) was used. While reading all the data, the researcher found several themes emerged for each question, which were highlighted as section headings, data were entered in respective sections of the findings, and articulated and consolidated into a coherent writing.

\section{Research findings}

The subsequent section presents findings of the study on the positive roles of the common courtyards, the cooperative management, and issues associated with the common courtyards for future design improvement.

\subsection{Courtyards as children's}

\section{playgrounds}

Away from traffic, the courtyards between buildings are safe spaces for children to play together, which is a big benefit for their social development, particularly if it is the only child at home. When the children are playing in the courtyard, they are always visible from indoors so that adults can watch over them from time to time, which makes housework and other indoor tasks possible. Whereas for the children, being able to play outside without adults gives them a sense of independence as they can explore the world within the safety of the community (figure 2). For the courtyard residents, coming home in the summer and seeing the children running through the sprinklers, riding their bikes, and the parents chatting in the courtyard, is a happy experience. Several of them mentioned that they are happy when hearing children playing in the courtyard.

From talking to parents, it appeared that the children living in common courtyards spend more time playing outdoors than those who do not have a common courtyard. Montgomery [17] likewise noted that in an American community, nearly two-thirds of the parents say that there is no place for their children to play within walking distance of their homes, and this is part of the reason that American children are now gaining more weight, leading to obesity.

At another cooperative housing in Toronto where the courtyard is locked from the outside with a pass card, strangers cannot easily wander in, which allows for a greater sense of security for children to play in it. Parents are always nearby, but they do not need to be quite as attentive, knowing that the children are safe, and that there are always adults around who can help if there is any problem arising.

However, some residents complained about people who run daycares out of their units taking over the courtyard regularly with many little children who tear at the plants or eliminate the possibility of a quiet read in the courtyard. Occasionally, the noise from a courtyard gathering or children's riding toys disturbs activities in the surrounding homes. There is also a grievance about bossy neighbors who want to control everything in the courtyard, yelling at the children from their windows.

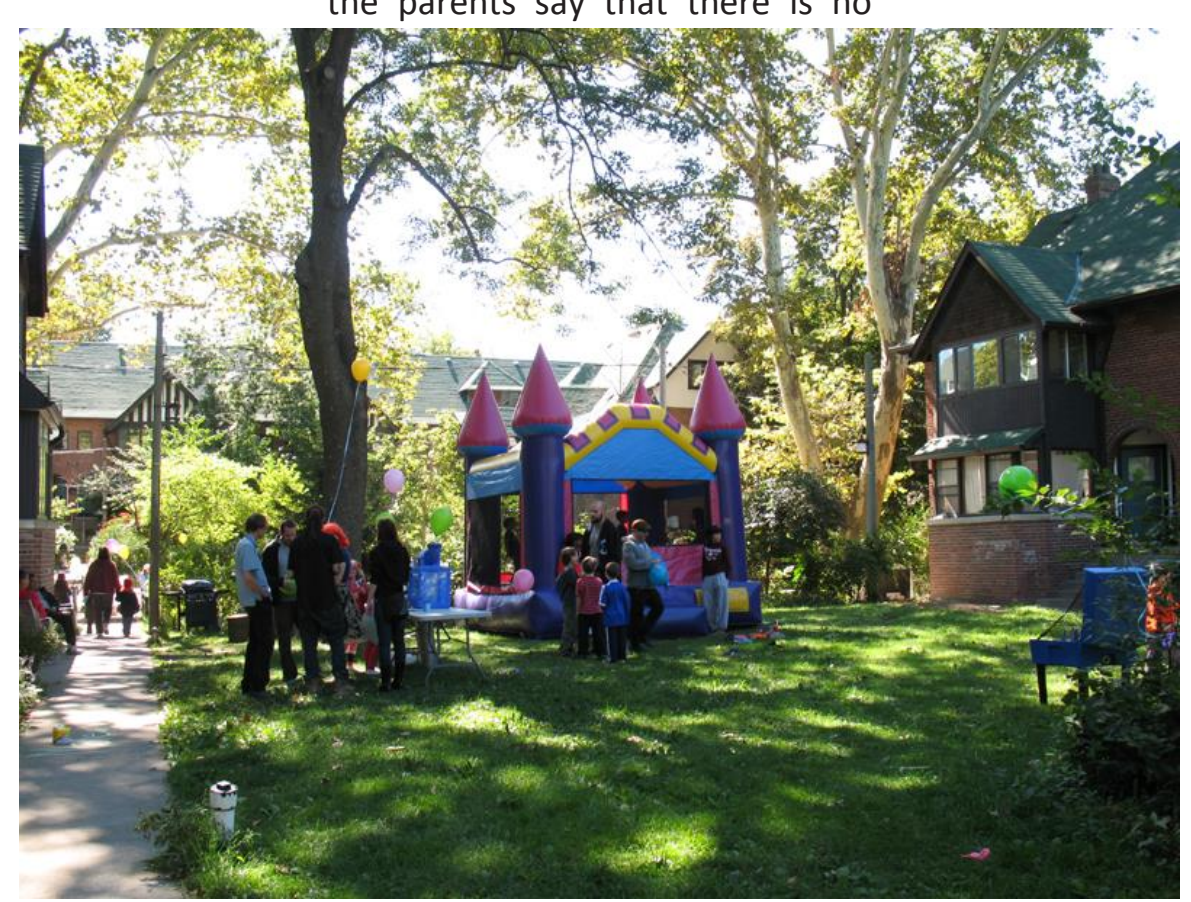

Figure 2. Centennial celebrations by the children at Bain Apartments Cooperative North Maples courtyard, Toronto, Ontario, Canada. Photo by the author 2013 


\subsection{Courtyards as landscaped gardens}

The Bain Apartments Cooperative in east Toronto has 26 buildings, of which only a few faces the street, all the rest face each other across nine semi-enclosed landscaped courtyards that are secluded without being isolated, where residents can enjoy the sunshine in them. The stoops provide a transitional space between private and shared spaces: one can sit out and talk to neighbors and passersby. The residents also have private outdoor spaces overlooking the courtyard, where they can be observers and participants at the same time. The narrow laneways between the buildings create another layer of community. Each household has its own little vegetable patch, where they can do gardening and harvesting together. The green plants and flowers are not only pleasant to look at, some are also edible. The dwellers are both market renters and subsidyreceivers; many have lived there all their lives who take pride in the courtyard surroundings. There is an excellent mix of the built environment with green space for relaxation, which is essential for a healthy lifestyle.

Three residents at Church-Isabella Residence Cooperative in downtown Toronto commented that their bedrooms on the second floor with French doors overlooking the courtyard offer an excellent view and a lovely breeze from the trees and grass that is good for their psyche. Meanwhile, they love the fact that they also have private outdoor spaces where they can relax, enjoy, and interact with others.

The landscape design of the common courtyards is central to community health and development. Design considerations should come before financial ones because they are vitally important. Some cooperative housing residents suggested reorganizing their courtyard space so that it is truly communal. For instance, have some tables and chairs on a patio for a comfortable visit, or even have an umbrella for sunshade. Better outdoor lighting is also essential so that it will not be too bright when raising their heads to see the night sky while walking around the area. A bib tap for watering the plants is also needed.

\subsection{Courtyards as social spaces}

The interview respondents at cooperative housing and cohousing in Canada felt that living in a common courtyard strengthens neighborly relations as when they step out their doors, they see a neighbor who is willing to lend a hand, and often there are boxes of vegetables straight from the garden to give to neighbors. The common courtyards create a sense of community and encourage interaction among neighbors as people hang out in the courtyards to chat or eat together. Adults not only have immediate friends to talk to, but also share responsibilities with, such as lawn mowing, raking leaves, and shoveling snow, usually on a goodwill, but sometimes as an organized effort resulting from courtyard meetings. When taking a walk around the courtyards, one can see many smiley faces.

At Bain Apartments Cooperative in east Toronto, there is a spirited range of respectful activities to participate in the courtyards, from people watching to stargazing. The courtyards are big enough to find one's own corner, and are ready for potlucks, sales, get-togethers, and "crafternoons" [ 2 ]. An understanding among the neighbors is that no matter who they are, they deserve respect in the courtyards.

At Bain common courtyards, the residents have an immediate

[2] Crafternoon is a word invented by the residents at Bain Apartments Cooperative, denoting afternoons when they get together with neighbors to do crafts sewing, quilting, mask making, paper mache, puppet making, etc. access to tools and knowledge, and a share of peoples' interests and expertise, such as dog care, childrearing, or health concerns. It is a relaxed space where the residents all learn to live with one another, a remedy to a sense of isolation or loneliness in an increasingly individualistic society. The residents know their neighbors; they plan and work together, share potluck suppers, or hold barbecue parties in the courtyards. Having many friendly neighbors, they have less concern for self or home security.

At Church-Isabella Residence Cooperative in downtown Toronto the common courtyard is where they hold spring and autumn parties, clean up after winter and prepare for the spring to come, read a book on a summer afternoon, and have barbecues and meals with their families, friends, and neighbors in the summer. The courtyard creates a possibility of spontaneous social interaction and builds and sustains the community.

At Cranberry Commons Cohousing in British Columbia, a resident noted that her community members would like to sit in the courtyard and talk with people, while others enjoy bringing their guitar and play music in the courtyard on summer days.

At WindSong Cohousing Community in British Columbia, a resident appreciated the opportunities offered by the common courtyard for brief encounters with people who were not particularly friends or ordinarily sought a visit with; thereby the courtyard helped strengthen the community ties. She also liked the spontaneous interactions with neighbors and the informal social encounters combining meetings with tea drinking.

At Wolf Willow Cohousing in Saskatchewan, two residents observed that their community members love the natural way they use the courtyard. They would meet spontaneously in the 
courtyard at various times of day when the weather permitted: coffee in the morning, cocktails or planned barbecues in the early evening, or just when they were watering the plants. All these events had made them happy to be part of the community.

A common courtyard could also be a convenient and inexpensive place to hold a marriage ceremony. For example, at Bain Apartments Cooperative in east Toronto, a resident revealed that a wedding took place at the Cedar Courtyard in 2012. At the Courtyard Housing Cooperative in midtown Toronto, the Property Manager mentioned that a wedding reception was held in the common courtyard in 1993. At Church-Isabella Residence Cooperative, some of the members also chose to hold their weddings in the common courtyard. It is anticipated that the common courtyard could also assist neighbors to find love, as a resident at Bain Apartments Cooperative frankly said that she wished a handsome old man could move into the unit beneath her, and that they would fall madly in love and move into a 2-bedroom unit above.

The common courtyards are central spaces for conducting cultural festivities. For example, the Bain Apartments Cooperative celebrated its Centenary (100 years) on September 13 and 14, 2013 , with live performances and activities in the common courtyards (figure 3).

In another cooperative housing in
Toronto, however, there was little use of the common courtyard at the time of the research (2013). Earlier on, the residents could sit around the picnic table, having picnics or wine in the evenings, and the members whose windows face the courtyard were relaxed about the noise. Some residents said they would like to return to those days and wished that the community uses the courtyard more often to keep it active by inviting all members to participate in social events, both casual and yard-work oriented, because the more they use the courtyard, the better it becomes. This would require frequent organized activities by the cooperative management.

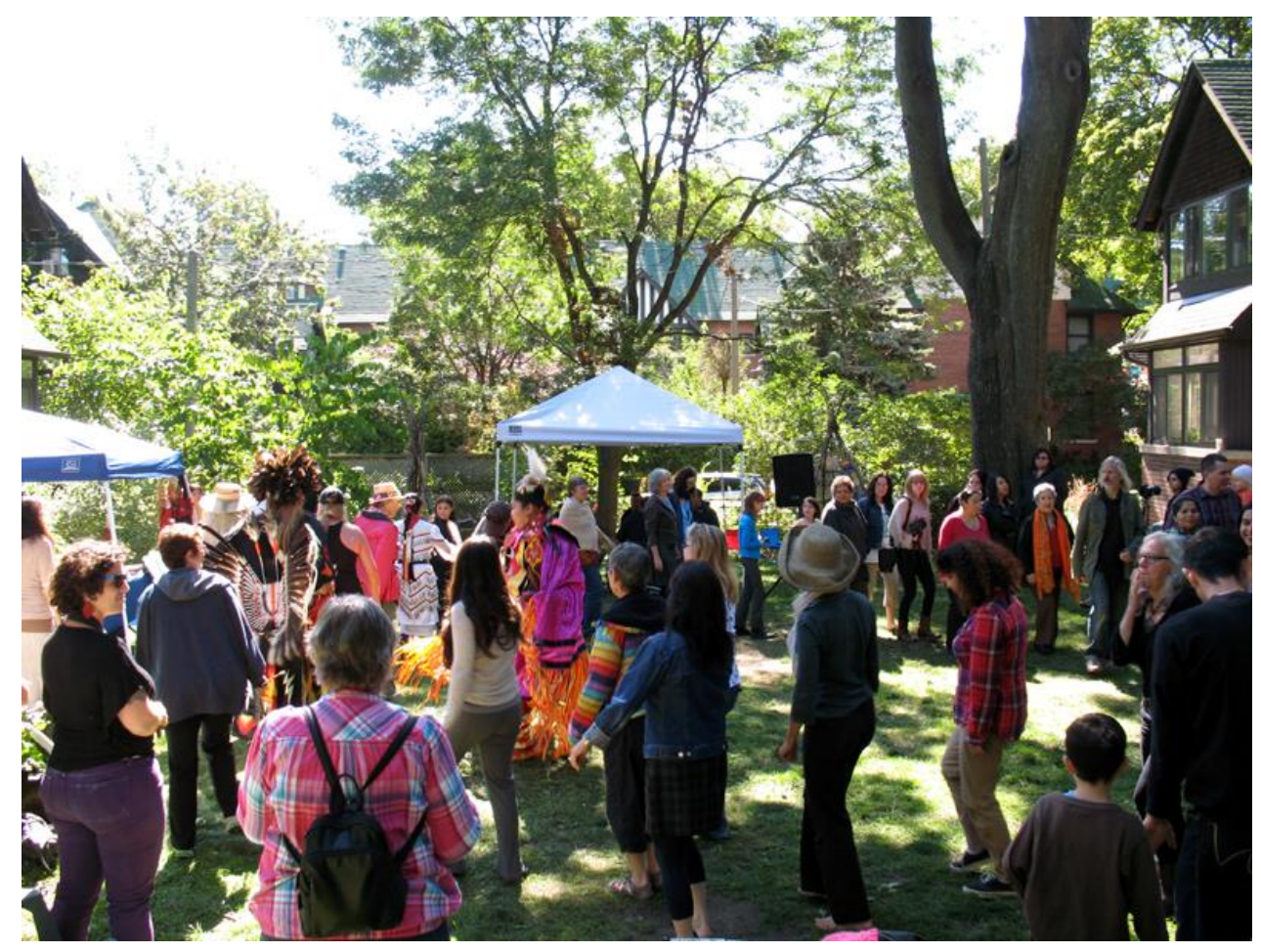

Figure 3. Centennial celebrations at Bain Apartments Cooperative North Maples courtyard, Toronto, Ontario, Canada. Photo by the author 2013

\subsection{Cooperative Management}

The cooperative management principles of democratic control by all the members have been a contributing factor to residents' happiness, because they are able to participate as volunteers in running the cooperative, and work together to create and sustain a safe and healthy place to live. The cooperative membership is open to all who accept the responsibilities of living by the cooperative principles, each member has a vote, and all members have an equal say in managing the cooperative. They set bylaws and policies, make decisions and elect leaders who report to them.
The cooperative housing creates a layered community. The residents belong to a courtyard, to a laneway, to the cooperative, and to various informal groups. The property and the buildings are owned by a non-profit organization, which is made up of all the members who currently live there. They collectively operate 
the property and are heavily involved in the maintenance work. They like the fact that the courtyard has been a unifying force on multiple levels.

However, some issues were raised by the residents that they required better cooperative policies and occupancy bylaws. Although tolerance is a good quality for communal living, it is sometimes necessary to discipline bad behaviors. For example, prohibit teenagers making loud noise in the common courtyard after $10 \mathrm{pm}$. On the other hand, the policies should also encourage residents to use the courtyard properly rather than restricting their activities such as barbecuing or gathering in it. Otherwise, they would feel intimidated to use the courtyard. Some residents complained about smokers smoking too close to the ground-floor windows facing the courtyard, while others lamented about teenage girls going naked in the mini pool in the beginning of summer. There were also occasions when female members felt uncomfortable walking by some males in the courtyard who were making inappropriate comments about them. Additionally, there is an issue of too many dogs urinating in the courtyard that damages the grass.

The residents wished to establish well-stated rules for the common courtyard, such as quiet times, the kind of toys that can be used, the type of furniture or decorations that can be kept, a budget for furniture and decorations, and responsibility for cleaning the courtyard. Dog owners should pick up dog feces, or no dogs allowed in the courtyard. To reduce noise, some residents suggested purchasing riding toys with rubber wheels, and putting a limit on the use of courtyard as daycare or children's playground as they can go to a nearby park to do so. Moreover, children should learn to respect their neighbors by not yelling.

\subsection{Differences in lifestyles}

Sharing a common courtyard has always been a challenge because people have different lifestyles. It is also related to intra-class differences in life. Learning to share a common space involves learning to accept noisier families, or families with diverse values that may not be in the everyday social sphere. This creates the opportunity to learn to set healthy boundaries, as well as open our minds to all kinds of differences.

Unwanted noise from neighbors has been an issue. Occasionally people get drunk in the courtyard late at night and make too much noise, disrupting and disrespecting other courtyard members. There is also sound transmission through the floors and walls that can be challenging if neighbors are loud. Sometimes a neighbor plays loud music (although that can happen in any high-density housing); other times parents let their children rule the courtyard, yelling and crying loudly. These are the unhappy things in the common courtyards that residents at cooperative housing or cohousing complained about.

\subsection{Lack of private backyards}

There was a criticism about the lack of privacy or personal space in the common courtyards, as the residents said they had to be dressed for public to use the courtyard. Some residents regarded the common courtyard as their private space and occasionally gathered a group of people outside their window for barbecue, but not everyone felt welcome to join.

Although many residents expressed they would like to raise their children in a common courtyard because of the benefits of having private home within a shared outdoor space, some of them still wanted to increase their privacy by having an individual outdoor space, such as a small private backyard for every household, in addition to the common courtyard. This improvement needs a creative solution to making people aware of the meaning of personal boundaries.
While others complained about some neighbors who did not understand boundaries would come over and talk their head off while they were reading a book. They suggested that higher and more robust fences within the city bylaws are needed to maximum privacy. Still others disapproved walking into the courtyard and having someone approach to them about volunteering for something or work that they would not want to do. Some participants felt obligated to participate in communal activities such as fall cleanup, shoveling snow, or courtyard meetings, when it was inconvenient for them to do so, or when they were having more of an indoor day.

\subsection{Lack of volunteerism and neighbor conflicts}

Some things that have contributed to residents' unhappiness at cooperative housing are not related to the courtyard, but to the cooperative management. The cooperative members found that it has been difficult to get residents to attend committee meetings, and the same people volunteered for committees repeatedly, while others would not volunteer at all. Some conflicts arose from people who had lived there many years and did not think things were done properly, they complained at meetings instead of getting involved. Not enough community resources had been put into conflict resolution and there was often not enough buy-in by the parties in conflict to resolve their issues. This reflects the wider cultural norms of Western society that emphasizes individualism and consumerism as primary values that undermine any adherence to cooperative values of sharing voluntarily and democratic control. The courtyards foster, but do not create, community; and they cannot prevent breakdowns in civility.

Improvements are difficult in a cultural climate where cooperative principles are not always valued. They are often paid lip service to, without enough financial support 
to provide adequate training to either staff or members. At best, people are often given the cooperative principles on paper or online, and then are told to follow them without any ongoing training on what they really mean because this is considered the responsibility of volunteers to implement, which can be faulty given the ups and downs of available volunteer time. It is therefore important to have good leadership among the residents, such as a good courtyard representative and many volunteer helpers. Every resident should pull together and put in volunteer effort to make their cooperative a better place.

\section{Proposed courtyard garden housing system}

Schmid [53] maintained that common spaces in a city can be as sites of encounter and exchange that would provide social network connections for a daily life that is open to a variety of possibilities, surprises, and innovations. Despite the issues mentioned above, the study shows that urban planning and design should always incorporate courtyard spaces because a courtyard is conducive to residents' happiness. The courtyard gardens may help prevent/alleviate people's mental health problems largely caused by social isolation, which is an increasingly common ailment in modern societies today [50, 54-56]. The courtyard may also help cultivate residents'/children's environmental awareness ${ }^{[57-59]}$.

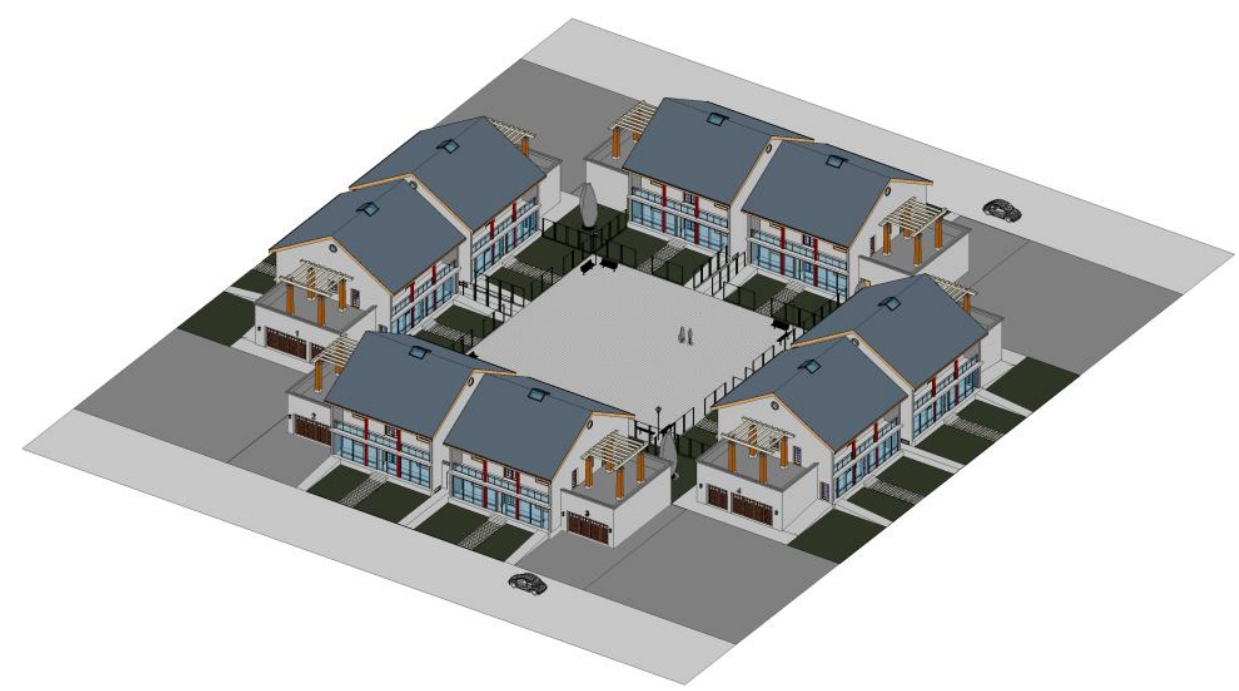

Figure 4. Proposed courtyard garden housing compound based on a system of $78 \mathrm{~m} \times 78 \mathrm{~m}$ standard block size, the common courtyard is $26 \mathrm{~m} \times 26 \mathrm{~m}$ shared by eight nuclear families, with each household enjoying a private garden of $12 \mathrm{~m} \times 6 \mathrm{~m}$ at the front and the back. Each housing unit measures $10 \mathrm{~m} \times 12 \mathrm{~m}$ (total 240 sqm) with a semibasement and 2 1/2 storeys. Source: Design and computer model by Zhang ${ }^{[54]}$

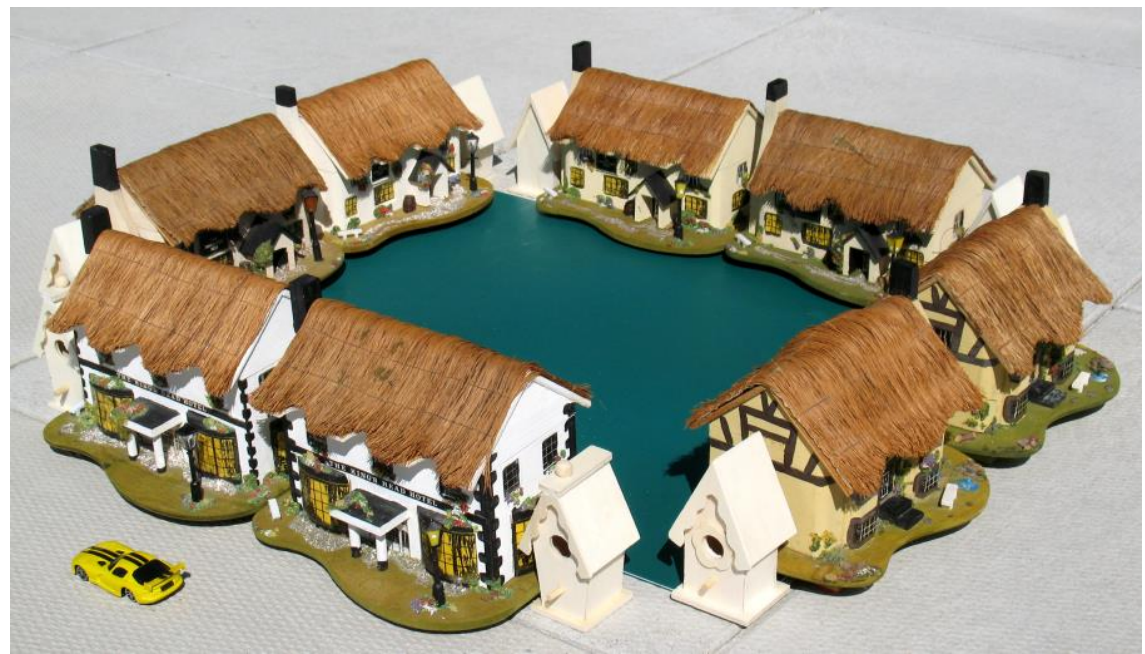

Figure 5. Proposed courtyard garden housing compound accommodating eight nuclear families. Source: Handmade music boxes as thatch-roofed English Cotswold cottages by Pauline Ralph; the courtyard configuration following the same planning principle suggested by Zhang [54]; layout and photo by the author 2016 


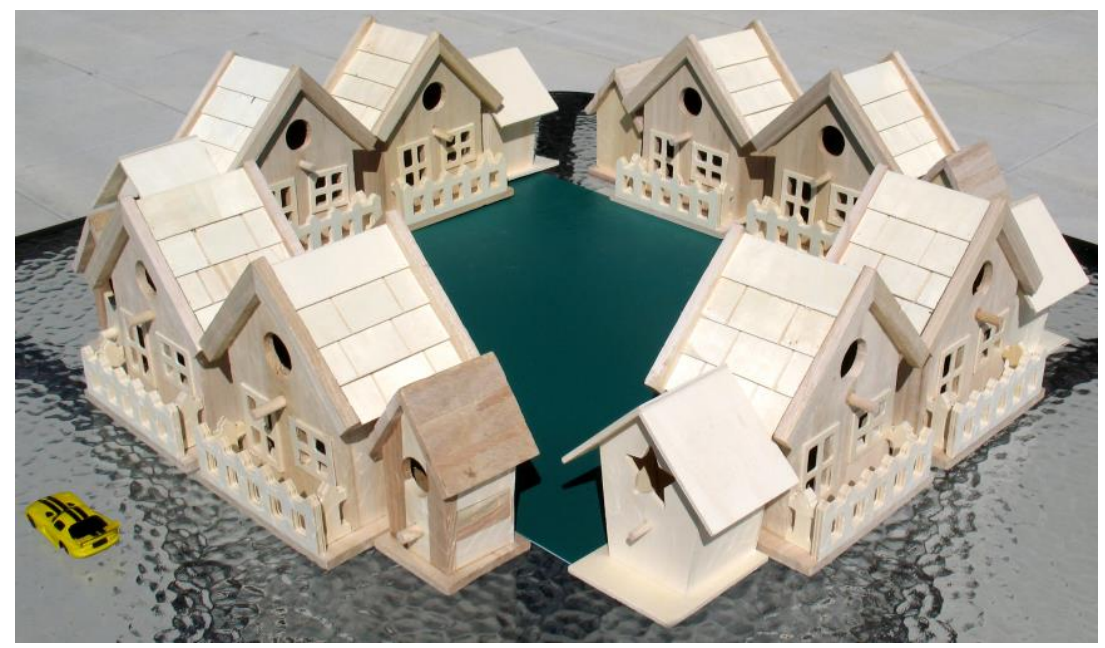

Figure 6. Proposed courtyard garden housing compound accommodating eight nuclear families. Source: Individual commercial wood houses made in China; the courtyard configuration following the same planning principle suggested by Zhang ${ }^{[54]}$; layout and photo by the author 2016

\section{Discussion and conclusions}

This evidence-based design(EBD) for a countyard garden housing systme(figures 4-6) has considered the comments made by residents in the research, and have attempted to honor both privacy and community through providing private front and back yards for personal activities, such as quiet readings and family gatherings, and a common courtyard for social activities, such as barbecue parties and physical exercises, and so on.

The optimum number for such a housing cluster is "eight" (8) units, as this number is considered appropriate for a comfortable social distance of $25 \mathrm{~m}$ between buildings [60], which is also in compliance with the minimum ratio of $1: 3$ for courtyard surrounding building height to distance ${ }^{[49-52,61]}$. This requirement will not only permit abundant natural light to penetrate the courtyard, but also protect residents' privacy of viewing through their windows. Moreover, this courtyard dimension of $26 \mathrm{~m} \times$ $26 \mathrm{~m}$ makes the compound neither too big nor too small to allow for good social interaction to take place. This configuration can be duplicated to generate a larger pattern in an urban or suburban setting, and it occupies less land than row housing ${ }^{[54]}$.

The three models (figures 4-6) demonstrate that regardless of the architectural style in façade design, or the size of each house unit, the courtyard system can be applied universally. The impact of the configuration on the urban design of neighborhoods and districts is that it would require zoning changes to legitimize courtyard housing system in Canadian cities and towns. The goal of the proposal is for the betterment of human habitat pattern to promote community development.

\section{Conflict of interest}

The residents who were unwilling to participate in the research might not like to see their communities being named here.

\section{Funding}

The finance of the project came from the researcher's personal assets.

\section{References:}

[1] Helliwell, J.F., Layard, R., and Sachs, J. (Eds.) (2012). World happiness report. New York, NY: Earth Institute, Columbia University. viewed December 9, 2017,

http://www.earth.columbia.edu/si tefiles/file/Sachs\%20Writing/2012 /World\%20Happiness\%20Report.p df

[2] Plato (1924). Laches, Protagoras, Meno, Euthydemus (translated by W.R.M. Lamb). Cambridge, MA: Loeb Classical
Library, Harvard University Press.

[3] Aristotle (1926). The 'art' of rhetoric (translated by J.H. Freese). Cambridge, MA: Loeb Classical Library, Harvard University Press.

[4] Aristotle (1999). Nicomachean ethics (translated by T. Irwin, 2nd ed.). Indianapolis, IN: Hackett.

[5] Seneca, L.A. (2012). Treatises on providence, on tranquility of mind, on shortness of life, on happy life. Charleston, SC: Nabu Press.

[6] Veenhoven, R. (2011) World Database of Happiness: Example of a Focused 'Findings Archive' (Working Paper no. 169). Germany: Federal Ministry of Education and Research. viewed December 9, 2017,

http://www.ratswd.de/download/ RatSWD_WP_2011/RatSWD_WP_ 169.pdf

[7] Bentham, J. (1789/2007) Introduction to the Principles of Morals and Legislation. Mineola, NY: Dover Publications.

[8] Frey, B.S. and Stutzer, A. (2000). Happiness prospers in democracy. Journal of Happiness Studies, 1, pp. 79-102.

[9] Graham, C. (2005). The economics of happiness. World Economics, 6(3), pp. 41-55. viewed December 9, 2017, https://www.brookings.edu/wpcontent/uploads/2016/06/200509. pdf

[10] Pew Research Center (2006). 
Are we happy yet? viewed December 9, 2017, http://www.pewsocialtrends.org/ 2006/02/13/are-we-happy-yet/

[11] Easterlin, R. (2003). Explaining happiness. Proceedings of the National Academy of Sciences, 100 (19), pp. 11176-11183.

[12] Kenny, A. (2001). Beyond a warm feeling: two more elements of well-being. In S. McCready (Ed.), The discovery of happiness (pp. 222-237). Naperville, IL: Sourcebooks.

[13] Kenny, A. and Kenny, C. (2006). Life, liberty, and the pursuit of utility: happiness in philosophical and economic thought (St. Andrews Studies in Philosophy and Public Affairs). Exeter, UK: Imprint Academic.

[14] Nias, D. (2001). Managing good and bad fortune: opportunities for happiness. In S. McCready (Ed.), The discovery of happiness (pp. 184-207). Naperville, IL: Sourcebooks.

[15] Argyle, M. (2001). Personality and happiness: who are the happy people? In S. McCready (Ed.), The discovery of happiness (pp. 172183). Naperville, IL: Sourcebooks.

[16] Bartlett, T. (2014). A tapemeasure for well-being. viewed December 9, 2017, https://www.chronicle.com/blogs/ percolator/a-tape-measure-forwell-being/34283

[17] Montgomery, C. (2013) Happy city. Toronto, ON: Doubleday Canada.

[18] Stanford Encyclopedia of Philosophy (2016). Hedonism. viewed December 8, 2017, https://plato.stanford.edu/entries /hedonism

[19] Bergsma, A. and Ardelt, M. (2012). Self-reported wisdom and happiness: an empirical investigation. Journal of Happiness Studies, 13, pp. 481-499.

[20] Bergsma, A., Poot, G., and Liefbroer, A.C. (2008). Happiness in the garden of Epicurus. Journal of Happiness Studies, 9, pp. 397423.

[21] Biswas-Diener, R., Kashdan, T.B., and King, L.A. (2009). Two traditions of happiness research, not two distinct types of happiness. Journal of Positive Psychology, 4(3), pp. 208-211.

[22] Huta, V. and Ryan, R.M. (2010). Pursuing pleasure or virtue: the differential and overlapping well-being benefits of hedonic and eudaimonic motives. Journal of Happiness Studies, 11, pp. 735-762.

[23] Kasser, T. and Sheldon, K.M. (2002). What makes for a merry Christmas? Journal of Happiness Studies, 3, pp. 313-329.

[24] Peterson, C., Park, N., and Seligman, M.E.P. (2005). Orientations to happiness and life satisfaction: the full life versus the empty life. Journal of Happiness Studies, 6, pp. 25-41.

[25] Ryff, C.D. and Singer, B.H. (2008). Know thyself and become what you are: a eudaimonic approach to psychological wellbeing. Journal of Happiness Studies, 9, pp. 13-39.

[26] Veenhoven, R. (2003). Hedonism and happiness. Journal of Happiness Studies, 4 (special issue on 'Art of Living'), pp. 437457.

[27] Waterman, A.S., Schwartz, S.J., and Conti, R. (2008). The implications of two conceptions of happiness (hedonic enjoyment and eudaimonia) for the understanding of intrinsic motivation. Journal of Happiness Studies, 9, pp. 41-79.

[28] Luò, Z.Z. (2006). Feng shui and modern residences, Chinese edition). Beijing: China City Press.

[29] Hamilton, J. (1860/2009/2015) The happy home. London: Forgotten Books.

[30] Harland, M. (1896/2011) The secret of a happy home. New York: The Christian Herald Association, Louis Klopsch, Proprietor, Bible House.

[31] Kennedy, D.J. (1997) Secret to a happy home. New Kensington, PA: Whitaker House.

[32] De Botton, A. (2006). The architecture of happiness. Toronto, ON: McClelland \& Stewart.

[33] Nayar, J. (2011). The happy home project: a practical guide to adding style and substance to your home. Maidenhead, Berkshire: Filipacchi Publishing.

[34] Paganelli, J. (2012). Happy home: twenty sewing and craft projects to pretty up your home. San Francisco, CA: Chronicle Books. [35] Winward, R. (2012). Happy home. London: Merrell Publishers.

[36] Chapin, R. (2011). Pocket neighborhoods. Newtown, CT: Taunton Press.

[37] Walljasper, J. (2013) How to design our neighborhoods for happiness. In: J. Walljasper and On The Commons, How to Design Our World for Happiness. Minneapolis, $\mathrm{MN}$ : On The Commons, pp. 10-11.

[38] Green Calgary (2013) Cohousing. viewed October 28, 2013, http://www.greencalgary.org/reso urces/co-housing-creating-

community-in-calgary

[39] Austin, A. (2013) 100 Bain Avenue, Toronto, Canada's Garden City 1913-2013. Toronto, ON: Alvyn Austin.

[40] Canadian Cohousing Network (2017). Building community with cohousing. viewed December 8, 2017, http://cohousing.ca

[41] McCamant, K. and Durrett, C. (1994). Cohousing: a contemporary approach to housing ourselves (2nd Edition). Danvers, MA: Ten Speed Press.

[42] McCamant, K. and Durrett, C. (2011). Creating cohousing: building sustainable communities. Gabriola Island, BC: New Society Publishers.

[43] Meltzer, G.S. (2005). Sustainable community: learning from the cohousing model. Victoria, BC: Trafford Press.

[44] ScottHanson, C. and ScottHanson, K. (2005). The cohousing handbook: building a place for community (2nd Edition). Gabriola Island, BC: New Society Publishers.

[45] Williams, J. (2005). Designing neighbourhoods for social interaction: the case of cohousing. Journal of Urban Design, 10(2), pp. 195-227.

[46] Cohousing Association of the United States (2017). Creating 
Community, One Neighborhood at a Time. viewed December 8, 2017, http://www.cohousing.org

[47] Knapp, R.G. (2005). Chinese houses: the architectural heritage of a nation. North Clarendon, VT: Tuttle Publishing.

[48] Ma, B. (1999). The architecture of the quadrangle in Beijing (Chinese edition). China: Tianjin University Press.

[49] Zhang, D. (2011). Courtyard houses of Beijing: past, present, and future. Saarbrücken, Germany: VDM Verlag.

[50] Zhang, D. (2013/2016). Courtyard housing and cultural sustainability: theory, practice, and product. Oxfordshire, UK: Ashgate/Routledge.

[51] Zhang, D. (2015). Classical courtyard houses of Beijing: architecture as cultural artifact. Space and Communication, 1(1), 47-68.

DOI:

$10.15340 / 2148172511881$

[52] Zhang, D. (2015). Courtyard houses of Beijing: lessons from the renewal. Traditional Dwellings and Settlements Review, 27(1), 69-82.

[53] Schmid, C. (2014). Networks, borders, differences: towards a theory of the urban. In N. Brenner (Ed.), Implosions/explosions: towards a study of planetary urbanization (pp. 67-80). Berlin: Jovis Verlag $\mathrm{GmbH}$.

[54] Zhang, D. (2015/2017). Courtyard housing for health and happiness: architectural multiculturalism in North America. Oxfordshire, UK: Ashgate/Routledge.

[55] Zhang, D. (2015). Sustainable urbanization in North America: courtyard housing and architectural multiculturalism. In J. Condie and A.M. Cooper (Eds.), Dialogues of sustainable urbanisation: Social science research and transitions to urban contexts (pp. 179-183). Penrith: University of Western Sydney.

[56] Zhang, D. (2016). Courtyard housing in North America: Chinese design for health and happiness. Urban Design International, 21(4), 281-297. DOI: 10.1057/udi.2016.6
[57] Zhang, D. (2008). Sustaining student involvement in schoolyard gardening: a curriculum debate. Interactions: The Ontario Journal of Environmental Education, 20(4), 10-16.

[58] Zhang, D. (2008). Sustainable schoolyard garden design. Interactions: The Ontario Journal of Environmental Education, 21(2), 20-29.

[59] Zhang, D. (2009). Schoolyard gardening as multinaturalism: theory, practice, and product. Saarbrücken, Germany: VDM Verlag.

[60] Gehl, J. (1971/2001). Life between buildings: using public space (translated by J. Koch). Copenhagen, Denmark: Arkitektens Forlag (The Danish Architectural Press).

[61] Zhang, D. (2006). New courtyard houses of Beijing: direction of future housing development. Urban Design International, 11(3), 133-150. 